\title{
The Philosophy of Mathematics
}

\author{
STEPHEN KÖRNER, M.A., PH.D.
}

Professor of Philosophy in the University of Bristol

This book explains the principal tenets of some of the more important philosophical theories about the content and context of mathematics. It then discusses the difference between conflicting theses about what mathematical systems are and conflicting programmes concerning what sort of mathematical systems should be constructed. These considerations lead to an independent discussion of the two main problems of the philosophy of mathematics. $12 \mathrm{~s} .6 \mathrm{~d}$.

\section{Hutchinson UNIVERSITY LIBRARY}

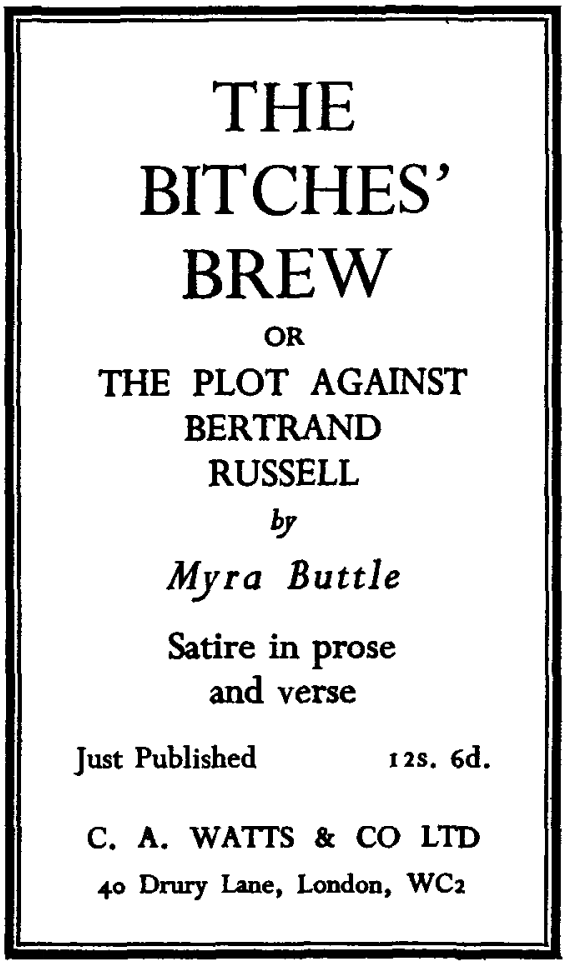

\section{The Idea of Order}

\section{Contributions}

to a Philosophy of Politics

BY HaNS BARTH

May 1960, vuI + 210 pp., Df 15.75 or $31 \frac{1}{2} \mathrm{~s}$.

Human society requires an order as realized, for example, in the state. Philosophy, the science of knowledge, has always considered the nature of this order one of the most important objects of its investigations.

It either approves or condemns the existing social or political order: this is the meaning and purpose of the great works of political and social criticism in the Western tradition. Politics, for its part, is not content with the mere factuality of order; the exercice of political power requires philosophical foundation and legitimation. Thus philosophy and politics, seemingly so unrelated, are fundamentally interrelated concepts.

D. Reidel Publishing Company DORDRECHT-HOLLAND 


\section{Ethics since 1900}

\section{MARY WARNOCK}

A brief account of the main ethical problems which have been discussed in this century in England, France, and the United States. Among the writings dealing with these problems which have been considered and analysed in detail are those of Bradley, Moore, Prichard, Ayer, Stevenson, and Sartre. (Home University Library) $8 s 6 d$ net

\section{The Scottish Philosophy of Common Sense}

\section{SELWYN ALFRED GRAVE}

¿... a bold, swift impression of the 1745-I843 period which conveys its intellectual excitements in a manner both entertaining and instructive, and which leaves us in no doubt that Reid and Stewart, Brown and Hamilton were all men of very genuine philosophical culture....' SCOTSMAN

\section{An Introduction to}

\section{Metaphysics}

\section{MARTIN HEIDEGGER}

\section{Translated by RALPH MANHEIM}

Martin Heidegger here investigates the meaning of being and man's understanding of it as they are recorded in philosophy and poetry, and, above all, in the language that underlies them both. (Yale University Press) $22 s 6 d$ net

\section{OXFORD UNIVERSITY PRESS}

\section{AUSTRALASIAN JOURNAL OF PHILOSOPHY}

\section{Contents May, 1960 Issue}

ARTICLES :

Douglas Gasking: Clusters.

BrIaN EluIs: Some Fundamental Problems of Direct Measurement.

DISCUSSION:

W. J. HuggetT: On Not Being Gulled by Ravens.

D. Stove: A Reply to Mr. Watkins.

J. W. N. WatkINS: Reply to Mr. Stove's Reply.

Putting Back the Clock: I.--J. E. MCGeChIE; II.-L. Goddard. CRITICAL NOTICE:

KưrT BAIER: Anscombe's Intention.

Reviews, Books Received, Notes AND News.

\section{HEFFER'S}

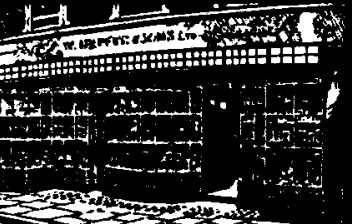

A CAMBRIDGE BOOKSHOP

THAT IS KNOWN

IN ALL PARTS

OF THE WORLD

W. HBPEER BONE LTD

Fobey Cary, Cambride. 


\section{DUNS SCOTUS \\ Philosophical Writings}

edited by ALLAN WOLTER O.F.M. This selection of the writings of Duns Scotus is taken from his Ordinatio, better known as his Oxford Commentary on the Sentences of Peter Lombard, and is here printed in Latin with an English translation. It presents his views on the chief aspects of the questions concerned with God and the human soul. Two questions deal with the existence and unicity of God, two questions with the human soul, one concerning its spirituality and its immortality, the other its ability to attain certain knowledge. One half-tone illustration.

NELSON'S PHILOSOPHICAL TEXTS

\section{NEL S O N}

Volume II

February 1960

No. 2

\section{R A T I O}

edited in co-operation with

H. B. Acton (London), A. Church (Princeton), H. Cherniss (Princeton),

G. Henry-Hermann (Bremen), K. R. Popper (London),

and J. W. N. Watkins (London)

by

Julius Kraft (Frankfurt a.M.)

R. M. HARE:

H. Khatchadourian:

N. ROTENSTREICH:

F. ZABEEH:

K. REIDEMEISTER:

H-J. RINCK:
A School for Philosophers Works of Art and Physical Reality Philosophy and the Economic Pattern Hume's Scepticism with Regard to Deductive Reason Intuition and Thought Blackstone and the Law of Nature

Review:

F. CAstBerg: Problems of Legal Philosophy (W. Müller-Freienfels)

E. NAGel and J. R. NeWMAN: Gödel's Proof (Wilhelm Ackermann) 


\section{MIND}

\section{A Quarterly Review of Psychology and Philosophy Edited by Prof. GILBERT RYLE \\ With the Co-operation of Prof. Sir F. C. Bartlett and Prof. C. D. Broad}

\section{CONTENTS FOR JULY 1960}

Escapism: The Logical Basis of Ethics:

A Technical Ought:

Popper on Science and the Presocratics:

On having the same Visual Experiences:

Good Reasons in Ethics: A revised Conception of Natural Law:

Doer and Doing:

Thoughts:

Discussions:

Necessary Propositions and "A priori" Knowledge in Kant:

Trurh, Futurity, and Contingency:

Truth, Futurity, and com autem non est procedere in infinitum: quia sic non esset aliquod primum mouens; et per
consequens nec aliquod aliud mouens, quia mouentia secunda non mouent nisi per hic quod sunt

mota a primo mouente ( $\mathrm{St}$. Thomas Aquinas):

Reply to Professor Körner:

Religious and Secular Beliefs:

S. Coval on Worship, Superlatives, and Concept Confusion:

P. H. NOWELL-SMITH and E. J. LEMMON B. J. DIGGS

G. S. KIRK

N. R. HANSON

A. CAMPBELL GARNETT

K. W. RANKIN

W. J. GINNANE

G. H. R. PARKINSON P. WOLFF

New Books

Notes

Annual Subscription 25 s post free; single copies $7 \mathrm{~s} 6 \mathrm{~d}$ postage $6 \mathrm{~d}$

Published for the MIND ASSOCIATION by

THOMAS NELSON \& SONS LIMITED PARKSIDE WORKS, EDINBURGH 9

\section{THE HIBBERT JOURNAL}

A Quarterly Review of Religion, Theology and Philosophy

Edited by The Rev. L. A. Garrard

$$
\text { List of Contents - July } 1960
$$

The Human Response to an Expanding Universe

Professor Harlow Shapley

Christian Values and the Arts

Sir Harry Lindsay

David Livingstone and Central Africa Today

Professor Vincent Harlow

The Metaphysic of Worship

The Rev. Dr. T. A. Burkill

The Accepting Attitude

Professor John Dixon Copp

Annual Subscription, $17 s .6 d$. post free. Single copies 5 s. net A free specimen copy of a back number will be sent on request

\section{GEORGE ALLEN \& UNWIN LIMITED}

